\title{
Impacts of birds of prey on gamebirds in the UK: a review
}

K.J. PARK,$^{1^{*}}$ K.E. GRAHAM, ${ }^{1}{ }^{\text {J. }}$ CALLADINE ${ }^{2}$ \& C.W. WERNHAM ${ }^{2}$

${ }^{1}$ Centre for Conservation Science, School of Biological \& Environmental Sciences, University of Stirling, Stirling FK9 4LA, UK

${ }^{2}$ BTO Scotland, School of Biological \& Environmental Sciences, University of Stirling, Stirling FK9 4LA, UK

Running page heading: Impacts of raptors on gamebirds

${ }^{*}$ Corresponding author.

Email: k.j.park@stir.ac.uk 
The influence of predators on the distribution, density and dynamics of their prey species has long been of interest to ecologists and wildlife managers. Where the prey population is also utilised by humans, conflicts may arise through competition for a limited resource. Because gamebird shooting in the UK provides employment, recreation and income, the impact of birds of prey on gamebird populations has been the subject of intense debate for many years. A variety of approaches has been used to assess the impacts that raptors have on gamebird populations. Here we review the applicability and limitations of the methods used and assess the scientific evidence for population-level and economic impacts of raptors on gamebird populations in the UK. Raptors may, in some situations, take large numbers of gamebirds and may be an important proximate cause of mortality, although few studies have assressed the impacts of raptors on either breeding or pre-shooting densities. Two exceptions are studies of Hen Harrier and Peregrine predation on Red Grouse on moorland in Scotland and Sparrowhawk predation on Grey Partridge on farmland in England. Both these studies suggested that raptors could have population-level impacts when their gamebird prey was already at low density. Studies on predation of captively bred gamebirds suggest that numbers taken by raptors at release pens vary considerably and in a few cases raptors have been documented killing relatively large numbers. On the whole, however, it appears that raptors account for a relatively small proportion of mortality among released birds and the impact on subsequent shooting bags is unknown. We summarise important gaps in current knowledge and recommend specific areas for future research.

Keywords: predation, game management, competition, mortality, hunting

The role of predation and the status of predators have become central themes in applied ecology, stemming in part from issues in species management and conservation (Ormerod 2002). Conflicts between humans and predators arise primarily because of competition for resources, the basic tenet being that predators reduce the density of prey that would otherwise be available to humans. Such conflicts can become highly controversial because the resources concerned are of economic value and the predators involved often have a high public profile and are legally protected (Woodroffe et al. 2005). In some areas, increases in predator populations following successful conservation programs and protective legislation have exacerbated past conflicts (e.g. Messmer 2000). Predator-prey interactions may also generate conservation conflicts in situations where one endangered species preys on another (e.g. Roemer \& Wayne 2003).

Gamebird shooting plays an important socio-economic role in communities in many European countries. A survey in the UK, for example, suggested that in 2004 almost a third of a million people participated in driven shooting of lowland game species (including ducks), and almost 50,000 people in walked-up and driven grouse shooting (Public \& Corporate Economic Consultants 2006). 
Gamebirds have a variety of mammalian and avian predators, including raptors, and several gamebird and raptor species are of high conservation concern (Valkama et al. 2005). Systematic data on many aspects of predator-prey conflicts are often sparse, in marked contrast to the wealth of anecdotal or subjective opinion on these issues (Graham et al. 2005). Consequently, there is widespread concern and debate amongst shooting and conservation stakeholders about the current role of raptors in limiting gamebird populations and their effects on game management (e.g. Harradine et al. 1997, UK Raptor Working Group 2000, Robson \& Carter 2001, Allen \& Feare 2003). Here we review raptor predation of gamebirds in the UK. The review covers all the UK's native and introduced galliforms that are, or were, hunted in the UK on a regular basis since the start of systematic population monitoring (i.e. after 1960): Grey Partridge Perdix perdix, Red-legged Partridge Alectoris rufa, Pheasant Phasianus colchicus, Capercaillie Tetrao urogallus, Black Grouse Tetrao tetrix, Red Grouse Lagopus lagopus scoticus and Ptarmigan Lagopus mutus. Important elements in the resolution of any human-wildlife conflict are the development of mitigation techniques and an understanding of the social aspects underlying such conflicts (e.g. Redpath et al. 2004, Woodroffe et al. 2005). The remit of the current study, however, was to review the scientific evidence for impacts on UK gamebird populations arising from raptor predation, not to consider mitigation techniques or conflict resolution.

The review aims to assess (i) the population and conservation status of gamebirds in the UK, (ii) evidence for population-level impacts of raptor predation and (iii) evidence for economic losses arising from raptor predation. We outline the generic limitations of the variety of techniques used to assess the impacts of predation on prey populations and summarise the available information on raptor predation of gamebirds in the UK. Further details and caveats of the studies cited in this paper can be found in Park et al. (2005).

\section{LITERATURE REVIEW}

Literature searches encompassed published (peer-reviewed), unpublished and web-based literature. Published material was identified initially using the ISI Web of Knowledge database (up to the end of 2006). Other published and unpublished material was identified by carrying out web searches for key words using the Google search engine and from the reference sections of papers and reports already obtained. The review included studies investigating raptor-gamebird interactions throughout the UK but also included those from continental Europe where these specifically addressed the issue of raptor impact on gamebird populations. We also conducted a small number of consultations and workshops with key stakeholder groups (see Acknowledgements), in order to assess research needs and identify further sources of data that might not have been found during the literature searches.

\section{ASSESSING IMPACTS OF PREDATION}

\section{What is a predation impact?}


The impact of predation on prey species depends largely on whether and how predators respond to changes in prey density (Begon et al. 1990). They can respond by changing individual predation rates (the functional response) or by changing their density (the numerical response; Solomon 1949). For the purposes of this review we have defined two types of impact: population-level and economic. The factors that cause the highest mortality within a population are not necessarily those that ultimately determine the population level, and large numbers of prey can be taken by predators without having an impact on the subsequent size of the prey species' breeding population (Newton 1998). This is because there are other sources of mortality (e.g. competition for territories or food) that may be higher at high prey densities (i.e. they are density dependent), and predation may be compensated for via reduced mortality from other factors or increased productivity from the remaining individuals. If predators selectively take weaker prey, for example heavily parasitised Red Grouse (Hudson et al. 1992), any impact on the population arising from predation may be reduced since such individuals would have died from other causes. For predation to have an impact at the population level, it must represent additive mortality (Begon et al. 1990, Redpath \& Thirgood 1997). We assumed that predation reduces the population size of a prey species if it ultimately compromises subsequent breeding numbers, as this is the figure upon which future populations will depend. Hence the take of individual prey by a predator does not necessarily equate to a population-level impact on the prey population.

Where gamebirds are hunted by humans, other predators may be regarded as competitors, and can potentially inflict an economic impact on shooting interests, regardless of whether or not they exert population-level impacts on the prey population. Quantifying the economic impact of predation is problematic, however. There is only direct economic impact if predators remove game that would not only otherwise have been available for hunting, but that would have actually been hunted. The economic impact of predation, therefore, does not necessarily equate to the number of individual prey taken by a predator. Predators may also exert economic impacts indirectly, without necessarily reducing population abundance, for example by disturbing birds on shoot days.

\section{How do we identify impacts?}

Methods that have been used to identify evidence of raptor predation and to assess or predict the impact of raptors on gamebirds include correlational analysis of abundance data, dietary analysis, survival analyses, experimental manipulation of predator numbers and questionnaire surveys. The applicability and limitations of each of these techniques are outlined in Table 1. Some studies investigating the impacts of predation have used a combination of techniques, and this may help considerably in interpretation of the data collected and strengthen any conclusions.

In addition to direct predation, predators can also affect prey population density by stimulating defensive strategies, the costs of which can include reduced energy income, lower mating success and increased vulnerability to other predators (see Preisser et al. 2005 for review). A recent metaanalysis of predator-prey interactions indicated that the impact of such trait-mediated interactions on 
prey demographics was at least as strong as direct consumption (Preisser et al. 2005). We know of no study to date, however, which has allowed the magnitude of any impact of trait-mediated interactions of raptor-gamebird interactions to be assessed.

\section{POPULATION AND CONSERVATION STATUS OF GAMEBIRDS IN THE UK}

Some gamebirds have been managed for shooting in the UK since at least the nineteenth century. The primary aim of game management is to maintain or increase the number of birds available to be shot in a given area during the shooting season. A combination of approaches can be used to achieve this:

1. Maintain or increase the size and/or productivity of wild populations through habitat management, provision of food and shelter, predator control and management of disease and parasites;

2. Minimise non-shooting losses of wild adult gamebirds through predator control and habitat management to control dispersal; and/or

3. Supplement wild populations with released birds through captive rearing

The last century has seen substantial declines in many wild populations of gamebirds and also in shooting bags (numbers of birds shot) in the UK (Tapper 1999). Shooting bags may be useful indicators of population size for gamebirds, although this has only been demonstrated empirically for Red Grouse (Cattadori et al. 2003). Reasons for these declines appear to be species specific. A large number of captive bred gamebirds are released each year for shooting, in the UK mainly the exotic Pheasant and Red Legged Partridge, both of which now have long established feral stocks (Table 2). In addition, small scale releases of the native Grey Partridge are made in some parts of the UK (Tapper 1999). Currently, around 25 million gamebirds are available for shooting annually in the UK, with galliforms, mainly Pheasant, Red Grouse and partridges comprising $70 \%$ of all shooting bags (Martinez et al. 2002). Table 2 outlines the most recent estimates of UK gamebird breeding population sizes (or numbers released and estimates of wild stocks for non-native species), trend information where available and population status within the UK. For the purposes of this review we have restricted consideration of population level impacts to native gamebird species. Studies investigating predation of captive bred birds are reviewed in the section on economic impacts.

\section{EVIDENCE FOR POPULATION-LEVEL IMPACTS OF RAPTOR PREDATION Red Grouse}

Long-term declines in Red Grouse numbers appear to have a number of causes. There was a reduction of around $20 \%$ in heather-dominated moorland across the UK between the 1940 s and the 1980s, as well as widespread degradation of remaining heather moorland (Thompson et al. 1995, Thirgood et al. 2000a). In addition, changes in management have occurred following sharp declines in gamekeeper numbers (Tapper 1992), and numbers of several predators species have increased: 
Red Foxes Vulpes vulpes, mustelids and corvids Corvus spp. are all thought to have a considerable impact on numbers of Red Grouse and are killed legally by gamekeepers (Hudson 1992).

Concerns surrounding the possible limiting effects of predation on Red Grouse populations centre on the importance of raptors. Red Grouse form part of the diet of several raptor species, such as Golden Eagle Aquila chrysaetos, Hen Harrier Circus cyaneus, Peregrine Falco peregrinus and Buzzard Buteo buteo (Mearns 1983, Redpath 1991, Watson et al. 1993, Graham et al. 1995). Using data from 14 studies across the UK of prey remains and pluckings, Ratcliffe (1993) calculated that Red Grouse comprised $40 \%$ by weight of all prey taken by Peregrines during the breeding season, and estimated that Peregrines took $1.6 \%$ to $5.3 \%$ of the Red Grouse population annually. In a Red Grouse population at high density in Glen Esk, non-territorial birds were those most likely to be killed by predators, and Peregrines took very few of these birds, though raptor numbers in this area were low at the time of the study (Jenkins et al. 1963, 1964). Data collated from areas with different Red Grouse densities indicated that whilst an estimated maximum of $12 \%$ of Red Grouse chicks were removed by Hen Harriers from a high density moor, up to $24 \%$ of chicks were taken from a lower density moor in the six weeks after hatching (Picozzi 1978, Redpath 1991). Comparisons between matched pairs of moors demonstrated that moors with Hen Harriers produced 17\% fewer Red Grouse than moors without harriers (Redpath 1991). Although these data do not demonstrate that harrier predation was responsible for reducing grouse production (there may have been other unknown differences between paired moors relating to management or habitat), evidence for a causal association is strengthened by data from one pair of moors where Red Grouse breeding success over time varied with harrier density (Redpath 1991). Of 729 Red Grouse corpses found during intensive searches at ten sites on managed moorland, $52 \%$ were reportedly killed by raptors in Scotland, and 42\% in England (Hudson et al. 1997). There is, however, the potential for some bias towards finding raptor kills in studies such as these, as raptors tend to leave more remains at a kill site than mammalian predators (Smith \& Willebrand 1999).

The most comprehensive study on the impacts of raptors on Red Grouse, the Joint Raptor Study (JRS), was conducted at six moorland study sites around the Langholm Estate in Scotland (Redpath \& Thirgood 1997, 1999, Thirgood et al. 2000a, b). The aim of the study was to assess whether predation by raptors could limit Red Grouse numbers to a level substantially below that which would occur in the absence of raptors (Redpath \& Thirgood 1997). The raptors present at Langholm were given complete protection from 1992, and over the following five years the number of breeding female Hen Harriers increased from two to 20 and the number of Peregrines from three to six pairs (Redpath \& Thirgood 1999). Based on survival and predation estimates from Langholm (1994-96), predation on adult Red Grouse by raptors during April and May was estimated to remove, on average, $30 \%$ of the potential breeding stock of grouse and, in summer, $37 \%$ of grouse chicks (Thirgood et al. 2000b). Taking into account compensatory mechanisms that may have been operating in the population, most losses of adults and chicks to raptors were thought to be additive to other causes of mortality, and to have reduced the numbers of grouse available to shoot in autumn by an estimated $50 \%$ in one year (Thirgood et al. 2000b). Over-winter loss of Red Grouse to raptors 
was estimated as $30 \%$ but it was not possible to determine the proportion of these grouse that would have survived in the absence of raptors (i.e. whether mortality due to raptors was additive or compensatory; Thirgood et al. 2000b). A simple model that combined the estimated reduction in breeding productivity with observed density dependence in winter losses predicted that, over two years and in the absence of raptors, grouse breeding numbers would have increased by 1.9 times and autumn numbers by 3.9 times (Thirgood et al. 2000b). Systematic counts of Red Grouse at Langholm showed that spring, summer and autumn densities decreased significantly between 1992 and 1998 (Thirgood et al. 2000b). Since 1998, spring densities have continued to decline (Baines \& MacMaster unpubl. data). The long-term declines in Red Grouse numbers at Langholm that occurred prior to the 1990s cannot be attributed to raptors, since raptors were uncommon in the area before 1990 (Thirgood et al. 2000a). From the results of the JRS, however, Thirgood et al. (2000a) concluded that raptors (Hen Harriers and Peregrines) prevented grouse numbers from increasing and reduced shooting bags. The study indicated that, in the absence of other predators, Peregrine predation would be unlikely to limit grouse numbers but, in addition to that from Hen Harriers, the level of raptor predation prevented the grouse population from increasing out of a low density population phase. Redpath and Thirgood (1999) also investigated how rates of predation by Hen Harriers and Peregrines varied with the density of Red Grouse across six different moors. The models suggested that the harriers took the highest proportion of grouse chicks at densities of around 67 chicks per $\mathrm{km}^{2}$, and that this predation could dampen grouse cycles and trap grouse at a low density equilibrium. The model of Peregrine predation suggested that a higher proportion of grouse was taken at grouse densities below 20 per $\mathrm{km}^{2}$.

The question clearly of interest to game managers is whether the findings of the Langholm study are representative of what could occur on other grouse moors if raptor densities were to increase. The question needs to be split into two parts. First, could similarly high densities of raptors (specifically Hen Harriers and Peregrines) occur on other grouse moors in the absence of measures to limit their numbers? Secondly, would these high densities of raptors then lead to the loss of driven shooting on other moors, as occurred at Langholm? In order to answer the first question, it is necessary to consider the extent to which the characteristics of Langholm are representative of those of other grouse moors. The vegetation at Langholm, and the density of Red Grouse supported prior to the JRS, both fall broadly within the range of UK moors, and the abundance of Meadow Pipits Anthus pratensis (one of the main sources of alternative prey for the Hen Harrier and a significant predictor of harrier breeding density; Redpath \& Thirgood 1999) at Langholm was not exceptional (Smith et al. 2000, 2001). These similarities suggest that Langholm might also be likely to support similar densities of small mammals to other moors, although empirical data are lacking. Redpath and Thirgood (1997) concluded that the impacts of harriers and Peregrines were likely to be higher on grouse populations on southern moors, and on grassy rather than heather-dominated moors. They also noted that Peregrines might also reach higher densities on southern than northern moors, due to the availability of racing pigeon prey. Smith et al. (2000) noted that Langholm moor is largely surrounded by rough grassland (which would be likely to hold much higher densities of alternative 
prey than, say, farmland), and that there is a need to consider how harrier densities (and breeding success, diet, hunting range and activity) are influenced by the wider landscape. A further issue of importance in this context is the suite of raptors present at Langholm compared to other grouse moors. It has been suggested that Golden Eagles may limit densities of other raptors (including Peregrine, Buzzard and Hen Harrier) in some areas (Ratcliffe 1993, Fielding et al. 2003), and the absence of Golden Eagles at Langholm might have resulted in high densities of harriers and peregrines becoming established.

To answer the second question, it is necessary to consider the ways in which Hen Harrier and Peregrine predation rates on grouse (their individual functional responses) and changes in the numbers of the predators (the numerical response) vary in relation to grouse density and the density of alternative prey species. If alternative prey densities are also similar to those at Langholm, then the remaining issue is that of the functional response to differing densities of grouse. The functional response curve for Hen Harrier predation on Red Grouse derived during the JRS (Redpath \& Thirgood 1999) was based largely on temporally disparate data from a number of moors, not on time series from the same moors. The critical accelerating part of the curve (indicating density-dependent predation of grouse chicks) was based on observations during four breeding seasons but largely from one moor, and the part of the curve corresponding to high grouse densities was based on data collected at two harrier nests on one moor in one year only (Redpath \& Thirgood 1997), so it is not clear to what extent the proportion of grouse chicks removed might decline as densities increase. Redpath and Thirgood (1999) recognised these limitations but pointed out that where prey numbers are limited by their predators, it may not be possible to measure predation rates over a wide range of prey densities.

\section{Ptarmigan}

Relatively few Ptarmigan are shot in the UK each year (see Table 2) and unlike other gamebirds covered in this review, no habitat management or predator control is conducted to enhance population sizes of this species. Foxes are one of the main predators of Ptarmigan, taking adults, chicks and eggs, whilst Golden Eagles are known to take adults and Carrion Crows Corvus corone to take eggs and small chicks (Watson et al. 1998, Watson \& Moss 2004). Other known predators include mustelids, Peregrines and Raven Corvus corax. To our knowledge, there have been no studies that have allowed any impacts of raptor predation on population densities to be assessed for Ptarmigan in the UK, although work by Nielsen (1999) indicated that predation by Gyrfalcons Falco rusticolus in Iceland had population-level impacts on Ptarmigan density and dynamics.

\section{Black Grouse}

Long-term declines in Black Grouse in the UK have been attributed to agricultural expansion and intensification, and this species is now only found in the uplands of Scotland, Wales and northern England (Baines \& Hudson 1995, Hancock et al. 1999). Recent declines have been associated with inappropriate grazing regimes and maturation of forests (Baines 1996, Calladine et al. 2002, 
Johnstone \& Lindley 2003, Pearce-Higgins et al. 2007). Deer and stock fences have also been implicated as a cause of high mortality (Baines \& Andrew 2003). The relative importance of these various proposed causes of decline in the UK, however, is difficult to assess. Predation is widely recognised as a major proximate cause of mortality and breeding failure in Black Grouse. Red Foxes, mustelids and corvids tend to be the main predators of nests and chicks, while Red Foxes and raptors kill adults (Angelstam 1984, Picozzi \& Hepburn 1984, Willebrand \& Marcstrom 1988). Woodland grouse species, and in particular Black Grouse, can form a large part of the breeding season diet of Goshawk Accipiter gentilis in Fennoscandia (Widén 1987, Tornberg 2001).

The proportion of adult Black Grouse taken by Goshawks each breeding season in Sweden was estimated using a combination of searching for prey remains at Goshawk nests during the breeding season and following radio-tagged Goshawk in winter over four years. This was estimated to be in the range of $4-14 \%$ of male spring numbers, and $6-25 \%$ of female spring numbers (Widén 1987). The minimum estimates represent the actual number of Black Grouse found at Goshawk nests and the maximum was based on the proportion, by weight, of Black Grouse in the Goshawk diet and the estimated food consumption of the Goshawk population during the breeding season. This latter figure would therefore represent an overestimate if there was a bias towards finding large prey (Widén 1987). In contrast, during the winter months Goshawks switched to taking Red Squirrels Sciurus vulgaris, and there was evidence of only two Black Grouse in the combined kills of four male and six female radio-tagged Goshawk over four winters (Widén 1987). Other studies have focused on the fate of Black Grouse monitored using radiotelemetry (Table 3). The length of time birds were followed for varied widely, in part due to the age differences of the birds, so care should be taken when comparing losses between studies. Each of these radio-tracking studies must be evaluated carefully due to the conflicting concerns expressed by those with experience of tracking this species about the effects of the tags and/or handling stress after attachment (Angelstam 1984, Caizergues \& Ellison 1997, 1998, Bowker \& Bowker 2003): some of this work suggests that the effects of some tags can be subtle and relatively long-term, specifically in the case of attachment to breeding females (Caizergues \& Ellison 1998). Researchers have dealt with this possibility in different ways (see Park et al. 2005 for details), and it is not possible to assess how these different approaches may have influenced the subsequent survival of individuals. If we assume that any effects of tagging are negligible in these studies, the results suggest that at some sites where key raptors are present (e.g. Goshawk and possibly Peregrine ), they may account for a high proportion of Black Grouse mortality, and where chick losses in particular are high, raptor predation could potentially lead to impacts on breeding Black Grouse populations. Despite this, no study has modelled the impact of raptor mortality on Black Grouse populations. In addition, the studies in Wales that have suggested raptor predation is an important source of mortality of Black Grouse chicks were conducted during a period when the numbers of lekking males at several of the study sites had increased (e.g. Lindley et al. 2003), so that, to date, no significant impacts on breeding densities have been demonstrated.

\section{Capercaillie}


Low breeding success appears to be the main demographic cause of the decline that has taken place in the Scottish breeding population of Capercaillie since the 1970s. This may be due to climate change, since warming in April has been increasingly delayed during the period 1975-1999, and breeding success is higher when warming proceeds earlier (e.g. Moss et al. 2001). In coniferous habitats in Fennoscandia, Capercaillie is important prey in the summer diet of Golden Eagles (Tjernberg 1981) and Goshawk (Widén 1987). In Scotland, they have been recorded in the diet of Buzzards and Golden Eagles (Marquiss et al. 1985, Swann \& Etheridge 1995). A radio-tracking study of Capercaillie in Abernethy and Glen Tanar showed that predators accounted for the known fates of three of 46 poults (6.5\%), four of 35 juveniles (11.5\%) and seven of 21 adult birds (33\%), mostly females (Catt et al. 1994, Moss et al. 2000). However, in neither of these studies were the authors able to distinguish between predator species or assess whether birds had been killed or scavenged. The relationship between Capercaillie breeding success and predator abundance within 14 forest areas across Scotland was investigated using composite measures of predator abundance (indices for Red Fox, Pine Marten Martes martes, Carrion Crow and raptors; Baines et al. 2004). Sightings (largely of Buzzards and Sparrowhawks Accipiter nisus) along a transect, were used as the index of raptor abundance. In comparison with the abundance of other predators, variation in raptor abundance did not appear to be associated with differences in Capercaillie productivity between sites: one composite index, comprising largely variation in the abundance of Red Fox and Carrion Crow but also raptors to a lesser extent, was negatively related to productivity, but another index accounting for a higher proportion of variation in raptor abundance was unrelated to productivity. Bilberry Vaccinium myrtillus cover in the forest field-layer was also related to Capercaillie breeding success and accounted for more of the variation than did the most significant index of predator abundance (Baines et al. 2004). To our knowledge, there have been no studies that have allowed any impacts of raptor predation on population densities to be assessed for this species.

\section{Grey Partridge}

The ecology and population dynamics of the Grey Partridge have been the subject of intensive research. Consequently, the main cause of the substantial population decline is known to be high chick mortality caused by reduced insect abundance following the introduction of herbicides in the 1950s (Southwood \& Cross 1969). Numerous studies have confirmed this relationship, although predation by Red Fox and corvids has also had an impact on autumn and spring stocks (e.g. Tapper et al. 1996). Hen Harriers and Marsh Harriers Circus aeruginosus have also been identified as important predators of Grey Partridge in France (Bro et al. 2001, 2006), where these two species cause up to $29 \%$ of female Grey Partridge mortality during breeding. Dietary studies have indicated that Grey Partridge comprise only a small proportion $(0.08-2.2 \%)$ of prey items found at Buzzard, Montagu's Harrier Circus pygargus and Sparrowhawk nests (Newton \& Marquiss 1982, Underhill-Day 1993, Swann \& Etheridge 1995). Of 42 wild Grey Partridge monitored over 12 months at two sites in Scotland, it was estimated that $8(19 \%)$ were taken by raptors, in comparison to total mortality levels 
of $60 \%$ (Parish \& Sotherton 2007). Buzzards and Sparrowhawks were both seen attacking, but not killing, partridges in this study but the identity of the main predator species is unknown.

Over-winter losses to shooting and predation (by raptors and Red Foxes) of Grey Partridge were calculated using count and bag data and predator signs on carcasses at one long-term study site in Sussex, England (Watson 2004, Watson et al. 2007). Kills by Sparrowhawk were far more common than kills by Buzzards. A deterministic population model for Grey Partridge (Potts 1986, Aebischer 1997) was then used to predict the effect of raptor predation on spring stocks of partridge under a range of different management scenarios and shooting pressure. Mortality of Grey Partridges to raptors over-winter was estimated at between $9.5 \%$ of autumn density and $15 \%$ of post-shooting density, depending on when most losses to raptors occurred (i.e. pre or post shooting). In the absence of shooting, this results in a reduction of the spring equilibrium density of $11-26 \%$ (Watson 2007). Model runs to examine the consequences of intensive released-based shooting were also examined. Using average shooting losses observed at the site, the model predicted that in the absence of raptors intensive shooting reduced spring equilibrium density by $68-85 \%$. Watson (2007) concluded that the impact of Sparrowhawk predation was greatest when Grey Partridge densities had been reduced to low levels by shooting and habitat loss and that, at this site, the proportion of wild birds shot exceeded the maximum sustainable yield. Extrapolating these results to other areas is not possible, as there are no comparable data from sites with higher densities of Grey Partridges and raptors and lower shooting rates (Watson 2004).

In order to estimate over-winter loss, it was assumed that the difference between the autumn and spring estimates of partridge numbers could be accounted for entirely by shooting and predation losses (i.e. no emigration, deaths to other causes), and that all birds not accounted for in shooting bags were taken by either Red Foxes or raptors. The proportion of birds taken by raptors was estimated using predator signs on carcasses, but because of the low density of partridges in the area, the sample size for this was very low, and therefore may not be representative of raptor predation on the whole population. In addition, the estimates used in the model (e.g. count data) were assumed to be measured without error, and the sensitivity of the spring stock predictions to varying these estimates is not reported. As such, the model is useful for exploring the relative effects of different management scenarios but it is unclear how much confidence can be placed on the absolute percentage reduction that raptors, in particular Sparrowhawks, may have on spring stocks.

\section{EVIDENCE FOR ECONOMIC LOSSES ARISING FROM RAPTOR PREDATION}

Shooting is socioeconomically important in parts of the UK, providing employment, recreation and income for businesses, landowners and many rural communities. The latest figures given by the United Kingdom Tourism Survey (Star-UK 2000), from domestic tourists only, show that expenditure where shooting is the main purpose of the trip is approximately $£ 34 \mathrm{~m}$ in the UK as a whole. Direct expenditure on countryside sports at 1996 prices was estimated as $£ 14.6 \mathrm{~m}$ for Red Grouse shooting alone and $£ 41 \mathrm{~m}$ for sports shooting (excluding Red Grouse shooting and deer stalking, but possibly including non-gamebird shooting; Cobham Resource Consultants 1997). Two major studies on 
grouse shooting in Scotland have evaluated capital generated and implications for local economies (McGilvray 1995, Fraser of Allander Institute 2001). Some 4500 people were employed in activities related to Red Grouse shooting in 2000, the equivalent of 940 full time jobs, supporting a total wage income of $£ 14.8 \mathrm{~m}$ and contributing $£ 17 \mathrm{~m}$ in GDP (Fraser of Allander Institute 2001). Any predation that reduces the numbers of gamebirds available for shooting, wild or released, could exert a direct economic impact on the shooting estate and potentially other parts of local economies. In this section we review studies that have estimated the number of captive-bred birds taken by raptors, and those that have attempted to assess the economic cost of raptor predation on both wild and released gamebirds. We also consider evidence for indirect economic losses arising from disturbance of gamebirds by raptors.

Large numbers of young, naïve birds in and around pens in late summer provide a source of highly concentrated prey that several raptor species are well suited to exploit (Thompson et al. 1997, UK Raptor Working Group 2000). However, there are few scientific studies on the impact of raptor predation on released birds. A number of factors are thought to influence the exposure of released birds to raptor predation, including the location of pens, timing of releases and age of released birds (Allen \& Feare 2003). Dietary studies have documented Pheasant and partridge remains in the diets of several raptors including Buzzard, Sparrowhawk, Marsh Harrier, Golden Eagle and Red Kite Milvus milvus (Walters Davies \& Davis 1973, Marquiss et al. 1985, Wildman et al. 1998, Sim et al. 2001). In the majority of these studies the percentage of prey remains comprising Pheasant is fairly low and (where stated) consists largely of chicks and young poults (0.6\% - 4.2\%; Newton \& Marquiss 1982, Underhill-Day 1985, Graham et al. 1995). A problem common to all of these studies is that of determining whether the Pheasants that were taken were killed directly or scavenged (Allen \& Feare 2003).

A variety of techniques have been used to try and quantify the number of captive-bred game birds taken by raptors at release pens or shortly after release (Table 4). Although a comparison of these figures is difficult due to differences in the duration of each study, most indicate that the average estimated loss to raptors is relatively low, ranging from about $1 \%$ to $8 \%$ of birds released. There are exceptions to this, however (e.g. Kenward et al. 1977, Parish \& Sotherton 2007), and the maximum losses reported suggest that predation at particular sites can be much greater (Table 4). The predation rate in all these studies will clearly depend to a great extent on the density of raptors, making extrapolations to areas which differ greatly in densities of raptors highly problematic.

In order to quantify the economic impact of predatory birds on game management, estimates of the number of birds taken by the predators that are subsequently unavailable for shooting, and of the numbers of birds actually shot are required. It is not sufficient simply to take the number of gamebirds taken by predatory birds and multiply it by the unit value of that gamebird. Two studies have attempted to estimate economic losses due to raptor predation of Pheasants (Kenward 1977, Allen et 
al. 2000; Table 4). Questionnaires were sent to 14 estates across England and independent observations by researchers were made at release pens (Allen et al. 2000). It has been estimated that $45 \%$ of Pheasants released will be shot in the first season after release (Tapper 1992). Based on a pen of 1000 poults and an average income to the estate of $£ 20$ per shot bird, losing $1 \%$ of released birds to raptors would constitute an income loss of $£ 90$ per pen. The maximum percentage loss found in this study (4.7\% of released birds) would represent an income loss of $£ 423$ per pen. Allen et al. (2000) point out that where losses are relatively small and predictable, additional birds may be released to compensate for losses incurred by predators and other factors so the cost of raptor predation may be lower than this. Where, however, pens are subject to higher losses that cannot be anticipated, the release of sufficient additional birds is often not practical. Kenward (1977) attempted to estimate the financial impact of Goshawk predation at a large estate releasing Pheasants in Sweden (see section 4). Of the 4300 birds released, an estimated 800 were taken by Goshawks constituting a loss of approximately $£ 5680$ based on a value of 50 SEK ( $£ 7.1$ in that year) per bird (Kenward 1977). This figure, however, assumes that all birds killed by Goshawks would have been shot whereas, as the authors point out, only 2000 (47\%) of the released birds were shot/trapped up or left to breed (Kenward 1977). If, therefore, $47 \%$ of Pheasants taken by Goshawks would been available to shoot, the economic cost of Goshawk predation is reduced to $£ 2670$ for the estate. The estimates of economic loss for both these studies (in the case of Kenward 1977, the derived estimate of $£ 2670$ ), assume that all raptor predation is additive to other forms of mortality, and may therefore represent overestimates of economic impact.

Hudson (1992) developed a simple economic model, encompassing the costs and income from Red Grouse management, which suggested that the costs of low intensity grouse moor management with the smallest driven bag sizes would be covered when the grouse density exceeded 60 per $\mathrm{km}^{2}$. The management intensities needed to produce the bag sizes typical for Langholm (one keeper per $10 \mathrm{~km}^{2}$ ) required Red Grouse densities of approximately 130 grouse per $\mathrm{km}^{2}$, which equates to 55 birds shot per $\mathrm{km}^{2}$ (Hudson 1992). On the basis of this model, Redpath and Thirgood (1997) estimated that an average of 2277 grouse must be shot annually on the $41.4 \mathrm{~km}^{2}$ moor at Langholm to break even financially. The cost of maintaining grouse moor management at Langholm in 1996 was reported to be $£ 99500$ whereas the income derived from the grouse shot that year was just £2680 (Redpath \& Thirgood 1997, Thirgood \& Redpath 1997). In addition, five gamekeeper jobs were lost as a result of the cessation of shooting at Langholm. It is wrong to assign the entire deficit to the impact of raptor predation, as there are many factors that influence the numbers of grouse shot. However, despite grouse numbers being cyclic, so that a net profit is not expected every year, grouse numbers were expected to peak in 1996, as occurred for neighbouring moors with which Langholm grouse numbers were previously known to cycle in parallel. It should be noted that the model developed by Hudson (1992) is now out of date, so that it is unlikely to reflect the absolute current economics of grouse moors. The reduction of grouse numbers at Langholm led to driven shooting being abandoned in 2000 (S. Thirgood, pers. comm.), and, in this case, has had a major economic impact. 


\section{Indirect effects of raptors on gamebirds}

In addition to direct predation of birds, concerns have been expressed about the possible disturbance by raptors of gamebirds at shoots, and indirect effects of raptors at release pens due to stress, vulnerability to disease and dispersal (Harradine et al. 1997, Robson \& Carter 1999, 2001, Allen et al. 2000). From the data available, however, there is little evidence of this. In the study of Pheasant release pens in England, there was no apparent relationship between the frequency with which raptors occurred at release pens and losses of Pheasants to other causes (Allen et al. 2000). The authors of the study suggested that it was possible that such indirect effects may only become apparent when the frequencies with which raptors occurred at release pens were much higher than occurred in their study.

An assessment of disturbance caused by raptors was conducted in North Yorkshire and Durham (Robson \& Carter 1999, 2001). Of 170 drives at 11 sites, disturbance by raptors was recorded on 20 drives, although 12 of these cases were reported by keepers to be relatively minor (Robson \& Carter 1999, 2001). Species implicated in these disturbances were Peregrine, Hen Harrier, Buzzard and also Raven. In Harradine et al. (1997) a subsample of respondents provided information on Grey Partridge and Red Grouse shoots. All of the keepers on 38 Grey Partridge shoots, and $84 \%$ of keepers on 136 Red Grouse shoots reported problems with raptors. For shoots dominated by Grey Partridge management, 49 incidents of birds being taken were reported during 1995, and in one case, a drive was lost. A total of 223 incidents were reported for Red Grouse shoots, with 27 drives being lost. The overall significance of such disturbance is unclear however, as the number of gamekeepers reporting such incidents was not specified so the proportion of respondents or drives experiencing these problems cannot be calculated.

\section{CONCLUSIONS}

The available evidence suggests that on a large scale, losses of reared gamebirds to raptors are relatively low, although they may be significant locally and may vary between gamebird species. There is also a considerable difference in the financial cost of losses of young birds and those of adult gamebirds. In order to demonstrate and quantify a direct economic impact, research is required to assess whether raptor predation of reared gamebirds actually reduces the numbers of gamebirds that would otherwise be shot.

Gamebirds, particularly young birds, occur in the diets of most raptors, but they usually constitute a small component of the diet (Cotgreave 1995, Allen \& Feare 2003). Some studies have estimated the proportion of raptor diet that comprises gamebirds but few have related this to the size of the gamebird population or assessed whether raptor predation affected the pre-harvest population or limited breeding numbers. A number of dietary studies have been unable to differentiate between prey species, and used general categories, such as 'other birds' or 'tetraonids', instead. Similarly, kills by raptors can often not be assigned to the specific raptor species concerned (e.g. Thirgood et 
al. 1998). In addition, interpreting causes of death from gamebird carcasses can be problematic. This review highlights a general need for differentiation between predator species (and between prey species in focal studies of predators) in dietary studies if these are to be used to assess the impact of raptors on gamebirds.

Given the importance of the Red Grouse system to many stakeholders, research to interpret further the findings of the JRS and subsequent related projects to quantify the overall population-level and economic impact of raptors on grouse shooting is warranted. Three strands of research are required: (a) studies to evaluate the likely densities that key raptor species would reach on other moors if allowed to breed freely; (b) further consideration of the functional and numerical responses of key raptor species to variation in the densities of their prey; and (c) an interdisciplinary study by ecologists and socio-economists of how additive losses of gamebirds to raptors would translate into economic impacts on the grouse shooting industry. Some work that will contribute towards these overall aims is already planned or underway (Park et al. 2005).

Data on population sizes and trends of Ptarmigan in the UK are lacking and there has been little research on raptor predation of this species. There have been few studies that have addressed the impacts of raptors on breeding densities of Capercaillie or Black Grouse and none has gone on to assess impact on the breeding population of the prey species in a fully quantitative manner. Most of the literature concerning these species has dealt with other causes of mortality, for example, disease, habitat loss, or other predator species. However, studies suggesting that raptors can be an important proximate cause of mortality for Black Grouse populations indicate that further research to test for impacts at the population level would be valuable.

The study of predator and prey dynamics simultaneously is very demanding, in terms of time, money and logistics. Consequently, information about the functional and numerical responses of raptors to gamebird populations in the UK is scarce, with one notable exception (Redpath \& Thirgood 1997), a shortcoming identified by a number of previous authors (e.g. Newton 1992, Martinez et al. 2002, Allen \& Feare 2003, Valkama et al. 2005). Extrapolating the results of individual studies to other geographical areas or raptor-gamebird systems is problematic as the degree of any impact is likely to be highly dependent on the densities of gamebirds, the species and densities of raptors present, the availability of alternative prey, and probably also variation in habitat. Existing research suggests that the impacts of raptors on gamebirds are likely to be greater when gamebird populations are already at low densities. Consequently, further research to investigate under what circumstances raptor predation is likely to prevent particularly vulnerable gamebird species (e.g. Black Grouse) from responding to conservation measures (e.g. habitat management), is required.

Finally, it should be recognised that controversy over the impacts of raptors on gamebird populations are not likely to be resolved simply by collecting more data on the scale of raptor predation. The 
recent European Concerted Action within the $5^{\text {th }}$ Framework Program: Reconciling Gamebird Hunting and Biodiversity (REGHAB) highlights the social and economic factors that are critical in this area and has suggested a number of ways in which conflict between raptor conservation and gamebird management may be reduced (e.g. Redpath et al. 2004, Valkama et al. 2005). 


\section{ACKNOWLEDGEMENTS}

We would like to thank the following people for their contribution to this review: Adam Smith, Alan Kirby, Andrew Stevenson, Andy Musgrove, Bert Burnett, Bob Swann, Brian Etheridge, Charles Connell, Chris Rollie, Chris Waltho, Colin Galbraith, Colin Shedden, Dave Parish, David Baines, David Cant, David Dunkley, David Noble, Des Thompson, Duncan Orr-Ewing, Graham Austin, Humphrey Crick, Ian Johnstone, Ian Newton, Jerry Wilson, John Harradine, John Marchant, Jon Hardey, Kenny Kortland, Kevin Duffy, Lynn \& Niall Bowser, Mike Bell, Mark Eaton, Mark Holling, Mark Rehfisch, Martin Milarky, Mick Marquiss, Mike Thornton, Murray Grant, Nick Sotherton, Nigel Harding, Patrick Stirling-Aird, Phil Whitfield, Rehema White, Roger Clark, Roger Sidaway, Ronnie Kippen, Rufus Sage, Simon Thirgood, Stephen Tapper, Stuart Newson, Wendy Mattingley. We would also like to thank Steve Redpath, an anonymous reviewer and the editor for comments and suggestions which improved the manuscript. We are grateful to the following organisations for funding this research: British Association for Shooting \& Conservation, The Game Conservancy Trust, The Game Conservancy Scottish Research Trust, The Heather Trust; Royal Society for the Protection of Birds, Scottish Association for Country Sports, The Scottish Executive, Scottish Gamekeepers Association; Scottish Natural Heritage, Scottish Rural Property and Business Association, Scottish Raptor Study Groups. 


\section{REFERENCES}

Aebischer, N.J. 1997. Gamebirds: management of the Grey Partridge in Britain. In Bolton, M. (ed) Conservation and the Use of Wildlife Resources: 131-151. London: Chapman \& Hall.

Aebischer, N.J. \& Baines, D. In press. Monitoring gamebird abundance and productivity in the UK: The GCT long-term datasets. Turkish J. Zool.

Allen, D.S. \& Feare, C.J. 2003. Birds of prey and lowland gamebird management. In Thompson, D.B.A., Redpath S.M., Fielding, A.H., Marquiss, M. \& Galbraith, C.A. (eds) Birds of prey in a changing environment: 427-442. Edinburgh: The Stationary Office.

Allen, D.S., Packer, J.J., Feare, C.J. \& Blanchard, C. 2000. Raptors and the rearing of Pheasants: problems and management needs. ADAS Consulting Ltd. Unpublished report to British Association for Shooting and Conservation. Available from DEFRA, Zone 1/08a, Temple Quay House, 2 The Square, Temple Quay, Bristol, BS1 6EB

Amar, A., Arroyo, B., Redpath, S.M. \& Thirgood, S. 2004. Habitat predicts losses of Red Grouse to individual hen harriers. J. App. Ecol. 41: 305-314.

Angelstam, P. 1984. Sexual and seasonal differences in mortality of the black grouse Tetrao tetrix in Boreal Sweden. Ornis Scan. 15: 123-124.

Baines, D. 1996. The implications of grazing and predation management on the habitats and breeding success of black grouse Tetrao tetrix. J. Appl. Ecol. 33: 54-62.

Baines, D. \& Andrew M. 2003. Marking of deer fences to reduce frequency of collisions by woodland grouse. Biol. Cons. 110: 169-176.

Baines, D. \& Hudson, P.J. 1995. The decline of the Black Grouse in Scotland and northern England. Bird Study 42: 122-131.

Baines, D., Moss, R. \& Dugan, D. 2004. Capercaillie breeding success in relation to forest habitat and predator abundance. J. App. Ecol. 41: 59-71.

Baker, H., Stroud, D.A., Aebischer, N.J., Cranswick, P.A., Gregory, R.D., McSorely, C.A., Noble, D.G. \& Rehfisch, M.M. 2006. Population estimates of birds in Great Britain and the United Kingdom. Brit. Birds 99: 25-44.

Begon, M., Harper, J.L. \& Townsend, C.R. 1990. Ecology: individuals, populations and communities. $2^{\text {nd }}$ Edition. Oxford: Blackwell Scientific Publications.

Bibby, C.J. 1987. Foods of breeding Merlins Falco columbarius in Wales. Bird Study 34: 64-70.

Bowker, G. \& Bowker, C. 2003. Lake Vyrnwy Black Grouse Project. Final Report. Report to Severn Trent Water by Lagopus Services.

Bowker, G., Bowker, C. \& Baines, D. 2007. Survival rates and causes of mortality in Black Grouse at Lake Vyrnwy, North Wales, UK. Wild. Biol.13: 231-237.

Bro, E., Arroyo, B. \& Migot, P. 2006. Conflict between grey partridge Perdix perdix hunting and hen harrier Circus cyaneus protection in France: a review. Wildl. Biol. 12: 233-247

Bro, E., Sarrazin, F., Clobert, J. \& Reitz, F. 2000 Demography and the decline of the grey partridge Perdix perdix in France. J. App. Ecol. 37: 432-448.

Bro, E., Reitz, F., Clobert, J., Migot, P. \& Massot, M. 2001. Diagnosing the environmental causes of the decline in Grey Partridge Perdix perdix survival in France. Ibis 143: 120-132.

Caizergues, A. \& Ellison, L. 1997. Survival of black grouse Tetrao tetrix in the French Alps. Wildl. Biol. 3: 177186.

Caizergues, A. \& Ellison, L. 1998. Impact of radio-tracking on black grouse Tetrao tetrix reproductive success in the French Alps. Wildl. Biol. 4: 205-212.

Calladine, J., Baines, D. \& Warren, P. 2002. Effects of reduced grazing on population density and breeding success of black grouse in northern England. J. Appl. Ecol. 39: 772-780.

Canning, P. 2006. The UK Game Bird Industry - A short study. Report to Defra. Lincoln: ADAS.

Catt, D.C., Dugan, D., Green, R.E., Moncrieff, R., Moss, R., Picozzi, N., Summers, R.W. \& Tyler, G.A. 1994. Collisions against fences by woodland grouse in Scotland. Forestry 67: 105-118.

Cattadori, I.M., Haydon, D.T., Thirgood, S.J. \& Hudson, P.J. 2003. Are indirect measures of abundance a useful index of population density? The case of red grouse harvesting. Oikos 100: 439-446.

Caughley, G. \& Gunn, A. 1996. Conservation Biology in Theory and Practice. Massachusetts, USA: Blackwell Science,

Cayford, J.T., Tyler, G. \& Macintosh-Williams, L. 1989. The Ecology and Management of Black Grouse in Conifer Forests in Wales. Newtown: RSPB.

Cobham Resource Consultants. 1997. Countryside sports their economic, social and conservation significance. The College of Estate Management, Reading, UK.

Cotgreave, P. 1995. Relative importance of avian groups in the diets of British and Irish predators. Bird Study 42: 246-252.

Cox, S.A., Peoples, A.D., DeMaso, S.J., Lusk, J.J. \& Guthery, F.S. 2004. Survival and cause-specific mortality of northern bobwhites in western Oklahoma. J. Wildl. Manage. 68: 663-671.

Crick, H.Q.P. Marchant, J.H., Noble, D.G., Baillie, S.R., Balmer, D.E., Beaven, L.P., Coombes, R.H., Downie, I.S., Freeman, S.N., Joys, A.C., Leech, D.I., Raven, M.J., Robinson, R.A. \& Thewlis, R.M. 
2004. Breeding Birds in the Wider Countryside: their conservation status 2003. BTO Research Report No. 353. (http://www.bto.org/birdtrends). Thetford, UK: BTO.

Dudzinski, W. 1992. Grey Partridge (Perdix perdix) predation relationships in cropland and forest habitat of central Poland. Gibier Faune Sauvage 3: 455-466.

Fielding, A.H., Haworth, P.F., Morgan, D.H., Thompson, D.B.A. \& Whitfield, D.P. 2003. The impact of Golden Eagles (Aquila chrysaetos) on a diverse bird of prey assemblage. In Thompson, D.B.A., Redpath S.M., Fielding, A.H., Marquiss, M. \& Galbraith, C.A. (eds). Birds of Prey in a Changing Environment: 221244. Edinburgh: The Stationary Office.

Fraser of Allander Institute for Research on the Scottish Economy, University of Strathclyde. 2001. An economic study of Scottish grouse moors: An update. Fordingbridge: The Game Conservancy Trust.

Gibbons, D.W., Reid, J.B. \& Chapman, R.A. 1993. The New Atlas of Breeding Birds in Britain and Ireland: 1988-1991. T. \& A.D. Poyser Ltd: London.

Graham, I.M., Redpath, S.M.\& Thirgood, S.J. 1995. The diet and breeding density of Common Buzzards Buteo buteo in relation to indices of prey abundance. Bird Study 42: 165-173.

Graham, K.E., Beckerman, A.P. \& Thirgood, S.J. 2005. Human-Predator-Prey conflicts: ecological correlates, prey losses and patterns of management. Biol. Cons. 122: 159-171.

Gregory, R.D., Wilkinson, N.I., Noble, D.G., Robinson, J.A., Brown, A.F., Hughes, J., Procter, D.A., Gibbons, D.W. \& Galbraith, C.A. 2002. The population status of birds in the United Kingdom, Channel Islands and Isle of Man: an analysis of conservation concern 2002-2007. Brit. Birds 95: 410-448.

Hancock, M., Baines, D., Gibbons, D., Etheridge, B. \& Shepherd, M. 1999. The status of Black grouse in Britain. Bird Study, 46: 1-15.

Harradine, J., Reynolds, N. \& Laws, T. 1997. Raptors and gamebirds. A survey of game managers affected by raptors. Wrexham: British Association for Shooting and Conservation.

Hudson, P.J. 1992. Grouse in space and time: the population biology of a managed gamebird. Hampshire: Game Conservancy Ltd.

Hudson, P.J., Dobson, A. \& Newborn, D. 1992. Do parasites make prey vulnerable to predation? Red grouse and parasites. J. Anim. Ecol. 61: 681-692.

Hudson, P.J., Newborn, D.\& Robertson, P.A. 1997. Geographical and seasonal patterns of mortality in Red Grouse Lagopus lagopus scoticus populations. Wildl. Biol. 3: 79-87.

Jenkins, D., Watson, A. \& Miller, G.R. 1963. Population studies on Red Grouse in northeast Scotland. J. Anim. Ecol. 32: 317-376.

Jenkins, D., Watson, A. \& Miller, G.R. 1964. Predation and Red Grouse populations. J. App. Ecol. 1: 183195.

Johnstone, I. \& Lindley, P. 2003. The proximate causes of Black Grouse breeding failure in Wales. Bangor: RSPB report to CCW (CCW contract science report No. 600).

Kenward, R.E. 1977. Predation on released pheasants by Goshawks in central Sweden. Swedish Game Research 10: 79-112.

Kenward, R.E., Hall, D.G., Walls, S.S. \& Hodder, K.H. 2001. Factors affecting predation by buzzards Buteo buteo on released pheasants Phasianus colchicus. J. App. Ecol. 38: 813-822.

Linden, H. \& Wikman, M. 1983. Goshawk predation on tetraonids: availability of prey and diet of the predator in the breeding season. J. Anim. Ecol. 52: 953-968.

Lindley, P., Johnstone, I. \& Thorpe, R. 2003. The status of black grouse (Tetrao tetrix) in Wales in 2002 and evidence for population recovery. Welsh Birds 3: 318-329.

Martinez, J., Vinuela, J. \& Villafuerte, R. 2002. Socio-economic and cultural aspects of gamebird hunting. Reconciling gamebird hunting and biodiversity. Finland: University of Turku.

Marquiss, M., Ratcliffe, D.A.\& Roxburgh, R. 1985. The numbers, breeding success and diet of Golden Eagles in southern Scotland in relation to changes in land use. Biol. Cons. 34: 121-140.

McGilvray, J. 1995. An economic study of grouse moors. Fordingbridge: Game Conservancy Trust.

Mearns, R. 1982. Winter occupation of breeding territories and winter diet of Peregrines in south Scotland. Ornis Scand. 13: 79-83.

Mearns, R. 1983. The diet of the Peregrine falcon Falco peregrinus in south Scotland during the breeding season. Bird Study 30: 81-90.

Messmer, T.A. 2000. The emergence of human-wildlife conflict management: turning challenges into opportunities. International Biodeterioration and Biodegradation 45: 97-102.

Moss, R. 1994. Decline of capercaillie (Tetrao urogallus) in Scotland. Gibier Faune Sauvage 11: 217-222.

Moss, R., Picozzi, N., Summers, R.W. \& Baines, D. 2000. Capercaillie Tetrao urogallus in Scotland demography of a declining population. Ibis 142: 259-267.

Moss, R., Oswald, J. \& Baines, D. 2001. Climate change and breeding success: decline of the Capercaillie in Scotland. J. Anim. Ecol. 70: 47-61.

Neilsen, O.K. 1999. Gyrfalcon predation on ptarmigan: numerical and functional responses. J. Anim. Ecol. 68: 1034-1050

Newton, I. 1992. Birds of prey. In M.J. Crawley (ed) Natural enemies: the population biology of predators, parasites and diseases: 143-162. Oxford: Blackwell Scientific Publications. 
Newton, I. 1993. Predation and limitation of bird numbers. Current Ornithology 11: 143-197.

Newton, I. 1998. Population limitation in birds. London: Academic Press.

Newton, I. \& Marquiss, M. 1982. Food, predation and breeding season in Sparrowhawks Accipiter nisus. J. Zool. 197: 221-240.

Ormerod, S.J. 2002. Applied issues with predators and predation: editor's introduction. J. App. Ecol. 39: 181188.

Parish, D.M.B. \& Sotherton, N.W. 2007. The fate of released captive reared grey partridge Perdix perdix; implications for reintroduction programmes. Wildl. Biol. 13: 140-149.

Park, K.J. 2004. Assessment and management of invasive alien predators. Ecol. Soc. 9: 12. [online] URL: http://ecologyandsociety.org/vol9/iss2/art12.

Park, K.J., Calladine, J.R., Graham, K.E., Stephenson, C.M. \& Wernham, C.V. 2005. The impacts of predatory birds on waders, songbirds, gamebirds and fisheries interests. Research contract FO4AC20A to Scotland's Moorland Forum. Available at: http://www.moorlandforum.org.uk/documents/PBRFinal.pdf

Pearce-Higgins, J.W., Grant, M.C., Robinson, M.C. \& Haysom, S.L. 2007. The role of forest maturation in causing the decline of Black Grouse Tetrao tetrix. Ibis 149: 143-155.

Picozzi, N. 1978. Dispersion, breeding and the prey of the hen harrier Circus cyaneus in Glen Dye, Kincardineshire. Ibis 120: 498-508.

Picozzi, N. \& Hepburn, L.V. 1984. A study of Black grouse in north east Scotland. In Hudson, P.J. \& Lovel, T. (eds) Proceedings of the $3^{\text {rd }}$ International Grouse Symposium: 462-480. Place and name of publisher

Potts, G.R. 1986. The partridge, pesticides, predation and conservation. London: Collins.

Potts, G.R. 1990. Numbers, harvest status and management recommendations for game species in the UK. Game Conservancy Trust Annual Review 33: 30.

Public \& Corporate Economic Consultants 2006. The Economic and Environmental Impact of Sporting Shooting. Commissioned report for British Association for Shooting \& Conservation, the Countryside Alliance and the Country Land and Business Association, in association with Game Conservancy Trust. Cambridge, UK. Available at: http://www.shootingfacts.co.uk/

Preisser E.L., Bolnick, D.I. \& Benard M.F. 2005. Scared to death? The effects of intimidation and consumption in predator-prey interactions. Ecology 86: 501-509.

Ratcliffe, D. 1993. The peregrine falcon. $2^{\text {nd }}$ Edition. London: T. \& A.D. Poyser Ltd.

Raven, M.J. \& Noble, D.G. 2006. The Breeding Bird Survey 2005. BTO Research Report No. 439. Thetford: British Trust for Ornithology,

Redpath, S. 1991. The impact of hen harriers on Red Grouse breeding success. J. App. Ecol. 28: 659-671.

Redpath, S., Arroyo, B.E., Leckie, F.M., Bacon, P., Bayfield, N., Gutiérrez, R.J. \& Thirgood, S.J. 2004. Using decision modeling with stakeholders to reduce human-wildlife conflict: a raptor-grouse case study. Cons. Biol. 18: 350-359.

Redpath, S.M. \& Thirgood, S.J. 1997. Birds of prey and Red Grouse. London Stationary Office: HMSO.

Redpath, S.M. \& Thirgood, S.J. 1999. Numerical and functional responses in generalist predators: hen harriers and peregrines on Scottish grouse moors. J. Anim. Ecol. 68: 879-892.

Redpath, S.M. \& Thirgood, S.J. 2003. The impact of hen harrier (Circus cyaneus) predation on Red Grouse (Lagopus lagopus scoticus) populations: linking models with field data. In Thompson, D.B.A., Redpath S.M., Fielding, A.H., Marquiss, M. \& Galbraith, C.A. (eds). Birds of prey in a changing environment: 499-510. Edinburgh: The Stationary Office.

Reif, V., Tornberg, R., Jungell, S. \& Korpimäki E. 2001. Diet variation of common buzzards in Finland supports the alternative prey hypothesis. Ecography 24: 267-274.

Robson, G. \& Carter, I. 1999. Do raptors disturb driven grouse shoots? A pilot study in northern England. English Nature Research Report no. 342. Peterborough: English Nature.

Robson, G. \& Carter, I. 2001. Do raptors disturb driven grouse shoots? A study in northern England. English Nature Research Report no. 401. Peterborough: English Nature.

Roemer, G.W. \& Wayne, R.K. 2003. Conservation in conflict: the tale of two endangered species. Cons. Biol. 17: $1251-1260$

Sim, I.M.W., Gibbons, D.W., Bainbridge, I.P. \& Mattingley, W.A. 2001. Status of the Hen Harrier Circus cyaneus in the UK and Isle of Man in 1998. Bird Study 48: 341-353.

Smith, A., Redpath, S. \& Campbell, S. 2000. The influence of moorland management on grouse and their predators. Bristol: DETR.

Smith, A., Redpath, S.M., Campbell, S.T., \& Thirgood, S.J. 2001. Meadow pipits, Red Grouse and the habitat characteristics of managed grouse moors. J. App. Ecol. 38: 390-400.

Smith, A. \& Willebrand, T. 1999. Mortality causes and survival rates of hunted and unhunted willow grouse. J. Wildl. Manage. 63: 722-730

Solomon, M.E. 1949. The natural control of animal populations. J. Anim. Ecol. 18: 1-35.

Southwood, T.R.E. \& Cross, D.J. 1969. The ecology of the partridge. III. Breeding success and the abundance of insects in natural habitats. J. Anim. Ecol. 38: 497-509.

Star-UK. 2000. United Kingdom Tourism Survey. London, UK. 
Swann, R.L. \& Etheridge, B. 1995. A comparison of breeding success and prey of the Common Buzzard Buteo buteo in two areas of northern Scotland. Bird Study 42: 37-43.

Tapper, S.C. 1992. Game Heritage. Fordingbridge: Game Conservancy Trust. .

Tapper, S.C. (ed.) 1999. A question of balance. Game animals and their role in the British countryside. Fordingbridge: Game Conservancy Trust.

Tapper, S.C., Potts, G.R. \& Brockless, M.H. 1996. The effect of an experimental reduction in predation pressure on the breeding success and population density of grey partridges Perdix perdix. J. App. Ecol. 33: 965-978.

Thirgood, S.J. \& Redpath, S. M. 1997. Red Grouse and their predators. Nature 390: 547.

Thirgood, S.J, Redpath, S.M., Hudson, P.J. \& Donnelly, E. 1998. Estimating the cause and rate of mortality in red grouse Lagopus lagopus scoticus. Wildl. Biol.4: 65-71.

Thirgood, S.J., Redpath, S.M., Haydon, D.T., Rothery, P., Newton, I. \& Hudson, P.J. 2000a. Habitat loss and raptor predation: disentangling long- and short-term causes of Red Grouse declines. Proc. Royal Soc. Lond. B 267: 651-656.

Thirgood, S.J., Redpath, S.M., Rothery, P. \& Aebischer, N.J. 2000b. Raptor predation and population limitation in Red Grouse. J. Anim. Ecol. 69: 504-516.

Thompson, D.B.A. Gillings, S.D., Galbraith, C.A., Redpath, S.M. \& Drewitt, J. 1997. The contribution of grouse management to biodiversity: a review of the importance of grouse moors for upland birds. In Fleming, V., Newton, A.C., Vickery, J.A. \& Usher, M.B. (eds). Biodiversity in Scotland: status, trends and initiatives: 198-212. Edinburgh: The Stationary Office.

Thompson, D.B.A., Macdonald, A.J., Marsden, J.H. \& Galbraith, C.A. 1995. Upland heather moorland in Great Britain: A review of international importance, vegetation change and some objectives for nature conservation. Biol. Cons. 71: 163-178.

Tjernberg, M. 1981. Diet of the Golden eagle Aquila chrysaetos during the breeding season in Sweden. Hol. Ecol. 6: 17-23.

Tornberg, R. 2001. Pattern of goshawk Accipiter gentilis predation on four forest grouse species in northern Finland. Wildl. Biol. 7: 245-254.

Tornberg, R., Korpimäki, E., Jungell, S. \& Reif, V. 2005. Delayed numerical response of goshawks to fluctuations of forest grouse. Oikos 111: 408-415.

UK Raptor Working Group. 2000. Report of the UK Raptor Working Group. Bristol: DETR/JNCC.

Underhill-Day, J.C. 1993. The foods and feeding rates of Montagu's Harriers Circus pygargus breeding in arable farmland. Bird Study 40: 74-80.

Underhill-Day, J.C. 1985. The food of breeding Marsh Harriers Circus aeruginosus in East Anglia. Bird Study 32: 199-206.

Valkama, J., Korpimäki, E., Arroyo, B., Beja, P., Bretagnolle, V., Bro, E., Kenward, R., Mañosa, Redpath, S.M., Thirgood, S. \& Viñuela, J. 2005. Birds of prey as limiting factors of gamebird populations in Europe: a review. Biol. Rev. 80: 171-203.

Walters Davies, P. \& Davis P.E. 1973. The ecology and conservation of the Red kites in Wales. Brit. Birds 66: 241-263.

Warren, P.K. \& Baines, D. 2002. Dispersal, survival and causes of mortality in black grouse in northern England. Wildl. Biol. 8: 91-97.

Watson, A. \& Moss, R. 2004. Impacts of ski-development on ptarmigan (Lagopus mutus) at Cairn Gorm, Scotland. Biol. Cons. 116: 267-275.

Watson, A., Moss, R. \& Rae, S. 1998. Population dynamics of Scottish Rock Ptarmigan cycles. Ecology 79: 1174-1192.

Watson, J., Leith, A.F. \& Rae, S.R. 1993. The diet of Golden eagles Aquila chrysaetos in Scotland. Ibis 135: 387-393.

Watson, M. 2004. The effects of raptor predation on Grey Partridges. Linacre College, Oxford: Unpublished DPhil Thesis.

Watson, M., Aebischer, N.J., Potts, G.R. \& Ewald, J.A. 2007. The relative effects of raptor predation and shooting on overwinter mortality of grey partridges in the United Kingdom. J. Appl. Ecol. 44: 972-982.

Widén, P. 1987. Goshawk predation during winter, spring and summer in a boreal forest area of central Sweden. Hol. Ecol. 10: 104-109.

Wildman, L., O'Toole, L.\& Summers, R.W. 1998. The diet and foraging behaviour of the Red kite in northern Scotland. Scottish Birds 19: 134-140.

Willebrand, T. \& Marcstrom, V. 1988. On the danger of using dummy nests to study predation. Auk 501: 6567.

Woodroffe, R., Thirgood, S. \& Rabinowitz, A. 2005. The impact of human-wildlife conflict on natural systems. In Woodroffe, R., Thirgood, S. \& Rabinowitz, A. (eds) People and Wildlife: 1-12. Cambridge, UK: Cambridge University Press. 


\section{TABLE LEGENDS}

Table 1. Techniques used to detect evidence of raptor predation and to assess or predict the impact of raptors on gamebirds. Their uses and limitations are based upon our evaluation when applied to studies of predation impact, but draws upon a number of texts including Caughley \& Gunn (1996), Newton (1998) and Park (2004). Studies reviewed for this paper have been given as examples of where particular techniques have been used. Inclusion of a study into one category (e.g. dietary analyses) does not imply exclusion from any other categories, although we have tried to ensure that it is the primary technique used. For dietary analyses we only included those studies that were able to quantify gamebird contribution to raptor diet rather than simply presence/absence. *Although not a controlled experiment, the Joint Raptor Study ${ }^{25,27,30,46}$ has been described as a "natural experiment" and provided comparisons of grouse densities before and after raptor protection and between sites with and without raptor protection. References: 1 = Baines et al. 2004; 2 = Bro et al. 2001; $3=$ Redpath 1991; 4 = Tornberg et al. 2005; $5=$ Amar et al. 2004; $6=$ Kenward 1977; $7=$ Kenward et al. 2001; $8=$ Widén 1987; 9 = Hudson et al. 1997; 10 = Watson 2004; 11 = Dudzinski 1992; 12 = Bibby 1987; 13 = Graham et al. 1995; 14 = Marquiss et al. 1985; 15, 16 = Mearns 1982, 1983; $17=$ Newton \& Marquiss 1982; 18 = Reif et al. 2001; 19 = Sim et al. 2001; 20 = Swann \& Etheridge 1995; 21, 22 = Underhill-Day 1985, 1993; 23 = Walters Davies \& Davies 1973; 24 = Watson et al. 1993; 25 = Picozzi 1978; 26 = Redpath \& Thirgood 1999; $27=$ Ratcliffe 1993; 28 = Thirgood et al. 2000b; 29 = Linden \& Wikman 1983; 30 = Tornberg 2001; 31 = Redpath \& Thirgood 1997; 32 = Redpath \& Thirgood 2003; 33 = Angelstam 1984; $34=$ Bro et al. 2000; 35 = Caizergues \& Ellison 1997; 36 = Cayford et al. 1989; 37 = Warren \& Baines 2002; $38=$ Bowker \& Bowker 2003; $39=$ Johnstone \& Lindley 2003; 40 = Parish \& Sotherton 2007; $41=$ Picozzi \& Hepburn 1984; $42=$ Turner \& Sage unpublished data; 43 = Cox et al. 2004; $44=$ Catt et al. 1994; $45=$ Moss et al. 2000; $46=$ Newton 1993; $47=$ Thirgood et al. 2000a; 48 = Allen et al. 2000; 49 = Harradine et al. 1997; 50, 51 = Robson \& Carter 1999, 2001.

Table 2

Most recent estimates of breeding population size in the UK, trends since 1960 and population status within the UK and Europe for gamebird bird species covered by the current review. References: $1=$ Baker et al. 2006; 2 = Raven \& Noble 2006; 3 = Tapper 1999; 4 = Potts 1990; 5= National Gamebag Census

(http://www.gct.org.uk/text01.asp?Pageld=164); 6 = Crick et al. 2004; 7 = Gibbons et al. 1993; 8 = Kortland et al. unpubl. data; 9 = Moss 1994; 10 = Sim et al. unpubl. data; 11 = Gregory et al. 2002; 12 = Canning 2006; 13 $=$ Game Conservancy Trust conservation guide

(http://www.gct.org.uk/conservationquide intro.asp?!mageld=6); 14 = Hudson 1992; 15 = Aebischer \& Baines in press.

a - Red list: species that are Globally Threatened according to the IUCN; those whose population size or range has declined rapidly in recent years; those whose population has declined historically and not shown a substantial recovery. Amber list: species with unfavourable conservation status in Europe (see note d); those whose population size or range has declined moderately in recent years; those whose population has declined historically but made a substantial recent recovery; rare breeders; and those with internationally important or localised populations. Green list: species that fulfil none of the other criteria. For full details of criteria see Gregory et al. (2002).

b - SPEC 3: species whose global populations are not concentrated in Europe but have Unfavourable Conservation Status within Europe (Endangered, Vulnerable, Rare, Declining, Localised or Insufficiently Known categories); SPEC 4: species whose populations are concentrated in Europe (>50\% global population or range in Europe) but have Favourable Conservation Status (Secure category); non-SPEC: not of conservation concern in Europe. For full details of criteria see BirdLife International/European Bird Census Council (2000). c - Annex I: Species in danger of extinction; species vulnerable to specific changes in habitat; species considered rare because of small populations or restricted local distribution; other species requiring particular attention for reasons of the specific nature of habitat. Annex II: species that, owing to their population level, distribution and reproductive rate, may be hunted throughout the European Community (Annex II-1) or in specific Member States (Annex II-2). See: http:/europa.eu.int/comm./ environment/nature/nature_conservation/focus_wild_birds/species_birds_directive. $\mathrm{d}$ - Bag sizes are the number of birds shot per $\mathrm{km}^{2}(100 \mathrm{ha})$ of total estate area for Red-Legged Partridge, Grey Partridge and Pheasant, and number of birds shot per $\mathrm{km}^{2}$ of moorland for Red Grouse.

Table 3

Radiotelemetry studies of Black Grouse. Mortality attributed to various fates (including raptor predation) is given as a percentage of the number of birds tagged, not as a proportion of birds that died during the study. 
a - It should be noted that poults captured in this study were still in their family groups but it is not clear how many poults from each group were radio-tagged. Since individuals from the same brood may not provide independent data on survival, survival estimates based on such data may be biased to an unknown degree.

$\mathrm{b}$ - In general, two chicks per family were chosen for radiotagging but in one case an entire brood of eight hand reared chicks was radiotagged. It is not possible to distinguish the mortality of the hand reared chicks from other chicks in the mortality figures.

Table 4

Studies assessing the losses of captively bred gamebirds to raptors and other causes of mortality. Average values are means unless otherwise stated.

a - in this study it is stated that "from some of the reported incidents it was possible to quantify the losses of pheasants and partridges attributed to raptors". From this it is unclear whether the mean losses quoted included responses from all the respondents including any game managers who had not experienced losses from raptors. 


\begin{tabular}{|c|c|c|c|}
\hline Technique & Description/methods/outputs & Advantages/uses & Disadvantages/limitations \\
\hline $\begin{array}{l}\text { Correlations in } \\
\text { abundance and } \\
\text { range }\end{array}$ & $\begin{array}{l}\text { - Correlations (temporal or spatial) between range or abundance of } \\
\text { predator with range or abundance of prey species }{ }^{1-4} \text {. }\end{array}$ & $\begin{array}{l}\text { - Data can be relatively easy to collect/may use } \\
\text { past records of abundance/range. } \\
\text { - Can provide persuasive circumstantial evidence } \\
\text { provided relationship is found at multiple } \\
\text { independent sites and confounding variables } \\
\text { can be eliminated. }\end{array}$ & $\begin{array}{l}\text { - Cannot derive causal relationship. } \\
\text { - Cannot inform on the mechanism of impact. } \\
\text { - Potential confounding variables (e.g. habitat } \\
\text { loss, overhunting, pollution) over same period } \\
\text { as introduction. }\end{array}$ \\
\hline $\begin{array}{l}\text { Dietary } \\
\text { Analysis }\end{array}$ & $\begin{array}{l}\text { - Analysis of predator diet used to assess which species may be } \\
\text { affected. } \\
\text { - Methods: direct observation (e.g. radio-tracking or observations } \\
\text { of predators } s^{5-8} \text { ), prey items returned to den/nest sites, stomach } \\
\text { contents, faecal/scat analysis, marks left on carcass/eggs }{ }^{9-11} ; \\
\text { stable isotope analysis. } \\
\text { - Potential outputs: presence or absence of prey in predator diet; } \\
\text { proportion of remains comprising of prey species }{ }^{12-24} ; \text { number of } \\
\text { prey items taken, proportion of prey population taken }{ }^{3,25-} \\
27 ; \text { energetic contribution to predator diet; contribution of predator } \\
\text { to proximate causes of mortality }{ }^{28} ; \text { rate of predation }{ }^{6,29,30} \text {. }\end{array}$ & $\begin{array}{l}\text { - Qualitative/quantitative information on potential } \\
\text { species affected by predatory species. } \\
\text { - In combination with demographic models of the } \\
\text { prey population, can provide an assessment of } \\
\text { impact }{ }^{0,28,31,32} \text {. } \\
\text { - With sufficient information can be used to } \\
\text { characterise the numerical/functional responses } \\
\text { of predator to prey species } \text { s }^{4,8,26,29,30} \text {. }\end{array}$ & $\begin{array}{l}\text { - Bias in dietary analysis can lead to under/over } \\
\text { representation of particular species/groups. } \\
\text { - Number of individuals/proportion of prey } \\
\text { population taken is not a measure of impact. } \\
\text { - Can be difficult to identify remains to prey } \\
\text { species. }\end{array}$ \\
\hline $\begin{array}{l}\text { Fate of marked } \\
\text { individuals }\end{array}$ & $\begin{array}{l}\text { - Proximate causes of mortality for a sample of the prey population } \\
\text { through mark-recapture/resighting methods or telemetry. } \\
\text { - Potential outputs: age/sex specific estimates of survival }{ }^{33-37} \\
\text { proportion of prey population (or adult/chick population) } \\
\text { depredated by different species } \\
\text { - Proportion of mortality events attributable to a given predator } \\
40,42 \text {. }\end{array}$ & $\begin{array}{l}\text { - In combination with modelling can provide an } \\
\text { assessment of impact }{ }^{10} \text {. } \\
\text { - Repeated studies can provide information on } \\
\text { changes in proximate causes of mortality that } \\
\text { could be linked with changes in e.g. predator } \\
\text { numbers, habitat quality. }\end{array}$ & $\begin{array}{l}\text { - Effect of handling on some species may } \\
\text { contribute to mortality. } \\
\text { - Possibility that tagging may increase } \\
\text { susceptibility to predation in some species }{ }^{43} \text {. } \\
\text { - Distinguishing between causes of mortality } \\
\text { e.g. between species of raptor }{ }^{44,45} \text { or } \\
\text { distinguishing between predation and } \\
\text { scavenging. } \\
\text { - Proportion of prey population taken is not a } \\
\text { measure of impact. }\end{array}$ \\
\hline $\begin{array}{l}\text { Experimental } \\
\text { manipulation of } \\
\text { predator } \\
\text { numbers* }\end{array}$ & $\begin{array}{l}\text { - Methods: differences in e.g. population size, survival etc can be } \\
\text { monitored using before/after or manipulated/control areas. A } \\
\text { combination of both provides the most rigorous design }{ }^{46} \text {. } \\
\text { - Potential outputs: changes to survival, breeding or foraging } \\
\text { success, population size }{ }^{31,47} \text { or changes in demographic } \\
\text { characteristics. }\end{array}$ & $\begin{array}{l}\text { - May be used: to test impact of predators; for } \\
\text { considering possible future management } \\
\text { strategies. } \\
\text { - May derive causal relationship. }\end{array}$ & $\begin{array}{l}\text { - Lack of response from prey population may } \\
\text { result from: inadequate design/sample size, } \\
\text { inappropriate timescale, need for other } \\
\text { restorative measures. } \\
\text { - In some situations numbers of other predators } \\
\text { may increase (i.e. meso-predator release) } \\
\text { - Resource and time intensive. } \\
\text { - Ethical considerations. }\end{array}$ \\
\hline Questionnaires & $\begin{array}{l}\text { - Surveys of gamekeepers, land owners etc. Have generally been } \\
\text { used to assess impacts of predators on reared gamebirds } \\
\text { /indirect effects of raptors e.g. scaring on shoot days. } \\
\text { - Potential output: causes of mortality, number/proportion of } \\
\text { gamebirds taken }{ }^{48,49} ; \text { incidence of raptors scaring gamebirds on } \\
\text { shoots }^{49-51} \text {. }\end{array}$ & $\begin{array}{l}\text { - Relatively low cost } \\
\text { - Can achieve wide geographical coverage }\end{array}$ & $\begin{array}{l}\text { - Can suffer from low return rates possibly } \\
\text { biasing results towards people who are } \\
\text { affected by, or have strong views on, particular } \\
\text { issues. } \\
\text { - Potential for error in recalling events e.g. } \\
\text { telescoping, where respondents incorrectly } \\
\text { bring events into the reference period. } \\
\text { - Distinguishing between causes of mortality } \\
\text { e.g. between species of raptor or } \\
\text { distinguishing between predation and } \\
\text { scavenging. }\end{array}$ \\
\hline
\end{tabular}

Table 1 


\begin{tabular}{|c|c|c|c|c|c|}
\hline Species & Current distribution & $\begin{array}{l}\text { Most recent } \\
\text { population estimates } \\
(95 \% \mathrm{CI})\end{array}$ & $\begin{array}{l}\text { Population trends since } \\
1960 \text { s }(95 \% \mathrm{Cl})\end{array}$ & $\begin{array}{l}\text { Conservation status: } \\
\text { BOCC listing }^{\text {a }} \text {; SPEC } \\
\text { status }^{\text {b }} \text {; EU Wild Birds } \\
\text { Directive Annex }^{\text {c }}\end{array}$ & Hunting status and bag sizes ${ }^{d}$ \\
\hline Pheasant & $\begin{array}{l}\text { Widespread, absent } \\
\text { in much of NW } \\
\text { Scotland }\end{array}$ & $\begin{array}{l}\text { 1,800,000-1,900,000 } \\
\text { females, } 2000^{1}\end{array}$ & 1994-2005: $+32(+25,+38)^{2}$ & $\begin{array}{l}\text { Introduced species; } \\
\text { Non SPEC }\end{array}$ & $\begin{array}{l}\text { c. } 20 \text { million released and } 12 \text { million } \\
\text { shot each year }{ }^{3,4} \text {, of which wild } \\
\text { stock comprises } 10 \% \text {; rate of } \\
\text { increase in bag size (and number of } \\
\text { releases) has stabilised since } 1990 \\
\text { at c. } 110 \text { birds per } \mathrm{km}^{2}(2001)^{5} \text {. }\end{array}$ \\
\hline $\begin{array}{l}\text { Red-legged } \\
\text { Partridge }\end{array}$ & $\begin{array}{l}\text { England except far } \\
\text { SW, Welsh borders, } \\
\text { eastern and southern } \\
\text { Scotland, eastern } \mathrm{N} \text {. } \\
\text { Ireland }\end{array}$ & $\begin{array}{l}72,000-200,000 \text { pairs, } \\
2000^{1}\end{array}$ & $\begin{array}{l}+55 \%(+40 \%,+72 \%) 1994- \\
2005^{2} \\
\text { Possible decline of wild stock } \\
\text { since } 1985^{3}\end{array}$ & $\begin{array}{l}\text { Introduced species; } \\
\text { SPEC } 2\end{array}$ & $\begin{array}{l}\text { c. } 2 \text { million released each year } \\
\text { bags increased by c. } 100 \% \\
\text { between } 1990 \& 2000 \text { (to c. } 22 \\
\text { birds per } \text { km }^{2} \text { in } 2001 \text { ) resulting } \\
\text { from an increase in birds released }{ }^{5} \text {. }\end{array}$ \\
\hline $\begin{array}{l}\text { Grey } \\
\text { Partridge }\end{array}$ & $\begin{array}{l}\text { Widespread except } \\
\text { most of Wales, NW } \\
\text { Scotland \& N. Ireland }\end{array}$ & $\begin{array}{l}70,000-75,000 \text { pairs, } \\
2001^{2}\end{array}$ & $\begin{array}{l}\text { Abundance: } \\
\text { - 86\% (-91, -80\%) 1967-20006 } \\
\text { - 40\% (-49, -29\%) 1994-2005² } \\
\text { Range: } \\
\text { - 18.7\% 1970-90 UK }\end{array}$ & $\begin{array}{l}\text { BOCC listing: Red; } \\
\text { SPEC 3; } \\
\text { EU Wild Birds Directive: } \\
\text { not listed }\end{array}$ & $\begin{array}{l}\text { Bags declined by c. } 50 \% \text { between } \\
1990 \text { \& } 2000 \text { to c. } 1 \text { bird per } \mathrm{km}^{2} \text { in } \\
2001) \text {; Voluntary restrictions on } \\
\text { shooting in place on many estates }{ }^{5} \text {. }\end{array}$ \\
\hline Capercaillie & $\begin{array}{l}\text { Pine woodland, } \\
\text { Scotland }\end{array}$ & $\begin{array}{l}1980 \text { birds } \\
(1284-2758), 2004^{8}\end{array}$ & $\begin{array}{l}\text { Decline in number and range } \\
\text { since the } 1970 \mathrm{~s}^{9} ; \text { Population } \\
\text { changes since } 1998 \text { not }^{8} \\
\text { statistically significant } ; \text { surveys } \\
\text { indicate some local increases } \\
\text { 1998-2004 }\end{array}$ & $\begin{array}{l}\text { BOCC listing: Red; } \\
\text { Non SPEC; } \\
\text { EU Wild Birds Directive: } \\
\text { Annex } 1\end{array}$ & Hunting is banned. \\
\hline $\begin{array}{l}\text { Black } \\
\text { Grouse }\end{array}$ & $\begin{array}{l}\text { Wales, Northern } \\
\text { England, Scotland }\end{array}$ & $\begin{array}{l}5082(3920-6156) \\
\text { males, } 2005^{10}\end{array}$ & $\begin{array}{l}\text { Range contraction since } \\
1960 s^{3}, \text { and severe decline in } \\
\text { numbers (c. }-74 \% \text { between the } \\
91 / 92 \text { and the } 95 / 96 \text { surveys) }\end{array}$ & $\begin{array}{l}\text { BOCC listing: Red; } \\
\text { SPEC 3; } \\
\text { EU Wild Birds Directive: } \\
\text { Annex } 1\end{array}$ & $\begin{array}{l}\text { A voluntary ban on shooting is } \\
\text { currently in place in most areas, but } \\
\text { this species remains legal quarry } \\
\text { and small numbers are shot each } \\
\text { year }^{12,13} \text {. }\end{array}$ \\
\hline Ptarmigan & $\begin{array}{l}\text { Upland areas } \\
(>1000 \mathrm{~m}) \text { in Scotland }\end{array}$ & 10,000 pairs, $1990^{1}$ & $\begin{array}{l}\text { Unknown in UK; } \\
\text { Overall trend in Europe } \\
\text { fluctuating }\end{array}$ & $\begin{array}{l}\text { BOCC listing: Green } \\
\text { Non SPEC } \\
\text { EU Wild Birds Directive: }\end{array}$ & $\begin{array}{l}\text { Analysis of bag data currently } \\
\text { underway (N. Aebsicher pers } \\
\text { comm.) }\end{array}$ \\
\hline Red Grouse & $\begin{array}{l}\text { Widespread in upland } \\
\text { areas across UK }\end{array}$ & 155,000 pairs, $2000^{1}$ & $\begin{array}{l}\text { Long-term and widespread } \\
\text { decline since mid 1970s; } \\
-15 \%(-32 \%, 6 \%) \text { 1994-2005² }\end{array}$ & $\begin{array}{l}\text { BOCC listing: Amber; } \\
\text { Non SPEC; } \\
\text { EU Wild Birds Directive: } \\
\text { Annex II-1/II-2 }\end{array}$ & $\begin{array}{l}\text { 1970-1990, c. } 450,000 \text { birds shot } \\
\text { per year }{ }^{14} \text {; Bags exhibit strong } \\
\text { fluctuations from year to year but } \\
\text { have declined by c. } 50 \% \text { during the } \\
\text { last century }{ }^{14,15} \text {; Bag size in } 2001 \\
\text { was c. } 10 \text { and } 46 \text { birds per } \mathrm{km}^{2} \text { in } \\
\text { Scotland and England respectively }{ }^{5} \text {. }\end{array}$ \\
\hline
\end{tabular}




\begin{tabular}{|c|c|c|c|c|c|}
\hline $\begin{array}{l}\text { Numberlage of } \\
\text { Black grouse } \\
\text { tagged }\end{array}$ & $\begin{array}{l}\text { \% estimated } \\
\text { loss from } \\
\text { raptor } \\
\text { predation }\end{array}$ & Other mortality & Raptor species & Study details & Source \\
\hline $\begin{array}{l}107 \text { juveniles, } \\
\text { subadults \& } \\
\text { adults }\end{array}$ & $15.9 \%$ & $\begin{array}{l}\text { Total losses }=29.9 \% \\
\text { Mammal }=13.1 \\
\text { Unknown cause }=0.9 \%\end{array}$ & Goshawk & $\begin{array}{l}\text { Fate monitored for up to } \\
\text { four months; } 90 \mathrm{~km}^{2} \text { study } \\
\text { area; Sweden. }\end{array}$ & Angelstam 1984 \\
\hline 18 adults & $5.6 \%$ & $\begin{array}{l}\text { Total losses }=38.9 \% \\
\text { Fox }=27.8 \% \\
\text { Fate unknown for } 56.6 \% \text { birds }\end{array}$ & Goshawk & $\begin{array}{l}\text { Fate monitored for } 28-426 \\
\text { days; Wales. }\end{array}$ & $\begin{array}{l}\text { Cayford et al. } \\
1989\end{array}$ \\
\hline $\begin{array}{l}93 \text { juveniles \& } \\
\text { adults }\end{array}$ & $24.7 \%$ & $\begin{array}{l}\text { Total losses }=48.4 \\
\text { Mammal }=12.9 \% \\
\text { Unknown predator }=5.4 \% \\
\text { Hunting }=5.4 \%\end{array}$ & $\begin{array}{l}\text { Golden Eagle } \\
\text { Goshawk }\end{array}$ & $\begin{array}{l}\text { Fate monitored for up to } \\
\text { two years at two sites; } \\
\text { France. }\end{array}$ & $\begin{array}{l}\text { Caizergues \& } \\
\text { Ellison } 1997\end{array}$ \\
\hline $\begin{array}{l}22 \text { adults }^{a} \\
48 \text { poults }\end{array}$ & $14.3 \%$ & $\begin{array}{l}\text { Total losses }=37.1 \% \\
\text { Stoats }=11.4 \% \\
\text { Fox }=2.7 \% \\
\text { Disease }=2.7 \% \\
\text { Collision }=4.3 \% \\
\end{array}$ & Peregrine & $\begin{array}{l}\text { Study conducted over two } \\
\text { years at } 15 \mathrm{~km}^{2} \text { site in } \mathrm{N} . \\
\text { England. }\end{array}$ & $\begin{array}{l}\text { Warren \& Baines } \\
2002\end{array}$ \\
\hline 75 chicks & $24.0 \%$ & $\begin{array}{l}\text { Total losses = 50-85\% each } \\
\text { year }(80 \% \text { overall); } 69-100 \% \\
\text { deaths attributed to predation; } \\
\text { where avian vs mammalian } \\
\text { predation differentiated }(n=20) \text {, } \\
\text { avian predators }=90 \%\end{array}$ & $\begin{array}{l}\text { Unidentified raptors; } \\
\text { confirmed Hen } \\
\text { Harrier in three cases }\end{array}$ & $\begin{array}{l}\text { Fate monitored for } 21-35 \\
\text { days; study conducted over } \\
\text { two years at five sites in } \\
\text { Wales. }\end{array}$ & $\begin{array}{l}\text { Johnstone \& } \\
\text { Lindley } 2003\end{array}$ \\
\hline $\begin{array}{l}54 \text { chicks }^{\text {b }} \\
31 \text { poults }\end{array}$ & $\begin{array}{l}53.7 \% \\
61.3 \%\end{array}$ & $\begin{array}{l}\text { Total losses = } 79.6 \% \text { (chicks), } \\
100 \% \text { (poults); } \\
\text { Foxes = } 20 \% \\
\text { Other causes }=10.6 \% \\
\text { Unknown fate }=12.9 \%\end{array}$ & $\begin{array}{l}\text { Goshawk \& } \\
\text { unidentified raptors }\end{array}$ & $\begin{array}{l}\text { Fate monitored for up to } \\
\text { three years at a } 54 \mathrm{~km}^{2} \text { site } \\
\text { in Wales }\end{array}$ & $\begin{array}{l}\text { Bowker \& Bowker } \\
\text { 2003; Bowker et } \\
\text { al. } 2007\end{array}$ \\
\hline
\end{tabular}

Table 3 


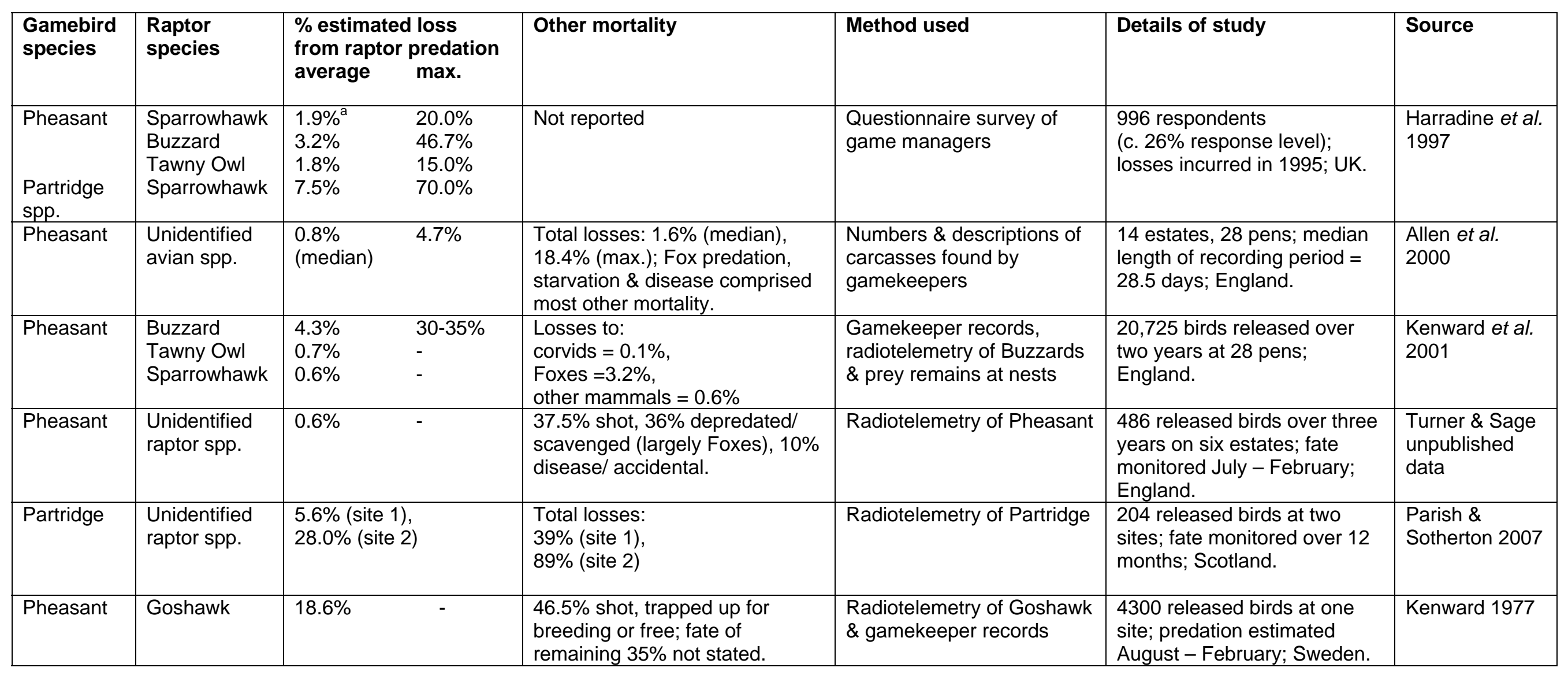

Table 4 